\title{
Evaluation of associations between asthma exacerbations and distance to roadways using geocoded electronic health records data
}

Jingyi He ${ }^{1}$, Mohsen Ghiasi Ghorveh ${ }^{2}$, Jillian H. Hurst ${ }^{3,4}$, Monica Tang ${ }^{5}$, Brooke Alhanti ${ }^{2}$, Jason E. Lang ${ }^{2,4}$ and Benjamin A. Goldstein ${ }^{1,2,3,4^{*}}$ (D)

\begin{abstract}
Background: Asthma exacerbations in children often require medications, urgent care, and hospitalization. Multiple environmental triggers have been associated with asthma exacerbations, including particulate matter 2.5 (PM2.5) and ozone, which are primarily generated by motor vehicle exhaust. There is mixed evidence as to whether proximity to highways increases risk of asthma exacerbations.

Methods: To evaluate the impact of highway proximity, we assessed the association between asthma exacerbations and the distance of child's primary residence to two types of roadways in Durham County, North Carolina, accounting for other patient-level factors. We abstracted data from the Duke University Health System electronic health record (EHR), identifying 6208 children with asthma between 2014 and 2019. We geocoded each child's distance to roadways (both $35 \mathrm{MPH}+$ and $55 \mathrm{MPH}+$ ). We classified asthma exacerbation severity into four tiers and fitted a recurrent event survival model to account for multiple exacerbations.

Results: There was a no observed effect of residential distance from 55+ MPH highway (Hazard Ratio: 0.98 (95\% confidence interval: 0.94, 1.01)) and distance to 35+ MPH roadway (Hazard Ratio: 0.98 (95\% confidence interval: 0.83, 1.15)) and any asthma exacerbation. Even those children living closest to highways (less 0.25 miles) had no increased risk of exacerbation. These results were consistent across different demographic strata.

Conclusions: While the results were non-significant, the characteristics of the study sample - namely farther distance to roadways and generally good ambient environmental pollution may contribute to the lack of effect. Compared to previous studies, which often relied on self-reported measures, we were able to obtain a more objective assessment of outcomes. Overall, this work highlights the opportunity to use EHR data to study environmental impacts on disease.
\end{abstract}

Keywords: Air pollution, Asthma, Electronic health records, Survival analysis

\footnotetext{
* Correspondence: ben.goldstein@duke.edu

'Department of Biostatistics \& Bioinformatics, Duke University, 2424 Erwin

Road, Durham, NC 27705, USA

2Duke Clinical Research Institute, Durham, NC, USA

Full list of author information is available at the end of the article
}

(c) The Author(s). 2020 Open Access This article is licensed under a Creative Commons Attribution 4.0 International License, which permits use, sharing, adaptation, distribution and reproduction in any medium or format, as long as you give appropriate credit to the original author(s) and the source, provide a link to the Creative Commons licence, and indicate if changes were made. The images or other third party material in this article are included in the article's Creative Commons licence, unless indicated otherwise in a credit line to the material. If material is not included in the article's Creative Commons licence and your intended use is not permitted by statutory regulation or exceeds the permitted use, you will need to obtain permission directly from the copyright holder. To view a copy of this licence, visit http://creativecommons.org/licenses/by/4.0/. The Creative Commons Public Domain Dedication waiver (http://creativecommons.org/publicdomain/zero/1.0/) applies to the data made available in this article, unless otherwise stated in a credit line to the data. 


\section{Background}

Asthma is one of the most common chronic respiratory diseases, affecting more than 25 million Americans, including $9 \%$ of children in the United States [1, 2]. Asthma exacerbations are acute episodes of worsening shortness of breath, wheezing, cough, and chest tightness that cause the majority of healthcare utilization and morbidity associated with asthma [3]. Over three million children suffer from at least one asthma exacerbation per year, with more than $10 \%$ of exacerbations requiring hospitalization [4]. Various clinical and environmental risk factors for asthma exacerbations have been identified. Previous studies have shown that outdoor air pollution, including fine particulate matter and gaseous pollutants from traffic and power generation can increase symptoms in children who have already been diagnosed with asthma [5-9].

Specifically, particulate matter 2.5 (PM2.5) and ozone $\left(\mathrm{O}_{3}\right)$, which form from motor vehicle exhaust, are well studied environmental triggers of asthma symptoms [10-12]. Areas close to major roadways can have high PM2.5 and CO levels [13, 14], and there is a growing body of evidence suggesting that proximity to car traffic sources can negatively affect asthma severity [15-25]. Importantly, the results of these studies are somewhat mixed, with a few studies either finding no association or weak associations between asthma exacerbations and distance to roadways [6, 26-28]. Some of the inconsistency in the results can be attributed to heterogeneity in study design, outcomes, cohort definition, and exposure assessments [28]. In particular, the majority of studies used self-reported questionnaires to collect exposure and outcomes data, which can result in potential misclassification and recall bias [26]. Thus, further studies are needed to evaluate the impact of distance to roadways on pediatric asthma exacerbations.

In this study, we sought to assess the association between the distance to two types of roadways $(35+\mathrm{MPH}$ and $55+\mathrm{MPH}$ ) and rates of pediatric asthma exacerbations in a medium sized eastern US city. To account for potential biases in the self-reporting of outcomes, we relied on data abstracted from our institution's electronic health record (EHR) system to objectively obtain information on asthma exacerbations.

\section{Methods}

\section{Data sources}

All data were extracted from the Duke University Health System Electronic Health Record (EHR) system. Duke University Health System consists of 3 hospitals - 1 tertiary care and 2 community-based - and a network of primary care and specialty clinics. As the primary provider in Durham County, North Carolina, it is estimated that $80 \%$ of Durham County residents receive their care through Duke University Health System [29]. For the purposes of this study we abstracted analytic data from our data warehouse covering the years January 1, 2014 to December 31, 2019.

\section{Study population}

We identified children (age 5-18), living in Durham County with asthma. Children had to be at least 5 years old to rule out unclear respiratory related diagnoses in younger children. To identify children with asthma we applied two definitions. Our first definition was encounterbased. A child had to have: 1) two outpatient encounters or one inpatient encounter with an asthma diagnosis (see Appendix Table 1 for ICD9/10 codes) and 2) a prescription for an asthma medication (see Appendix Table 2). Our second definition was problem list-based. Problem lists are an EHR feature that serves as a comprehensive list of patient diagnoses that is intended to serve as a snapshot of the patient's health status. To be included under the problem list-based definition, a child had to have 1) asthma on their problem lists and 2) a prescription for an asthma medication. The positive predictive value of this computable phenotype is $97 \%$ [30].

In order to account for differential follow-up times, person-time was calculated from time of positive asthma identification until censoring. Censoring was based on aging out of the cohort $(>=18)$, an indicated address outside of Durham County, or at the last known encounter.

\section{Primary exposure}

The primary exposure in our study was the residential distances to two types of roadways: roads with U.S. Census feature Class Code A1 (55+ MPH with limited access only accessible via ramps) and A2 (35+ MPH-primary road without limited access) [31-33], with these speeds corresponding to highways and major roadways, respectively $[15,16,18,24]$. We abstracted the address information of each individual in our cohort from our EHR system and geocoded them using ArcGIS (version 10.5; ESRI Inc., Redlands, CA). The accuracy of all address information was manually checked with Google Maps to verify the existence of residences at each address. Addresses were treated as a time-varying exposure based on when a child moved to a new address, as indicated in the EHR. Map figures were made with ArcGIS software.

Straight-line distance to roadways, which was calculated using ArcGIS, was used as our primary exposure (See Fig. 1). Durham County has three major roadways that intersect in central Durham (Fig. 1). For children who live within this triangular intersection, straight-line distance might not accurately capture exposure. We therefore also constructed radial density measures of 1.0 


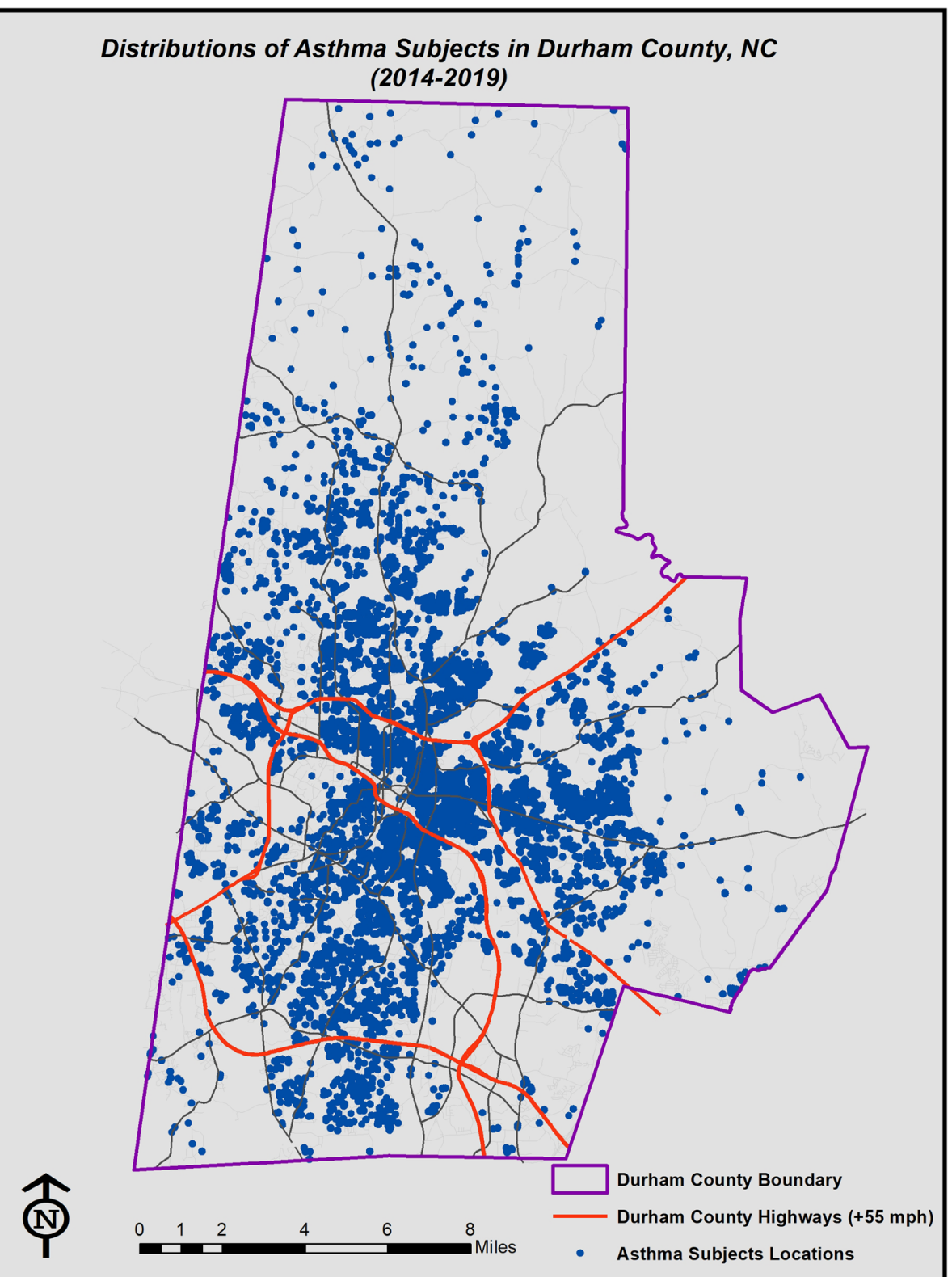

Fig. 1 Living location of children in our cohort and proximity to major roadways in Durham County. These blue dots represent the living location of every children with asthma in our cohort, and the red lines are the 55+ MPH highways in Durham. The edge of the county is the rural area. This map was generated with ArcGIS software

mile in order to evaluate exposures associated with proximity to more than one roadway (Fig. 2).

\section{Outcome of interest}

The primary outcome of interest was an asthmarelated exacerbation, which was defined as any encounter with an asthma-related ICD9 or-10 code and a prescription for a systemic steroid (see Appendix Table 1). We further categorized exacerbations into four different outcome tiers based on severity (listed in decreasing severity): 1) inpatient encounters lasting more than $24 \mathrm{~h}, 2$ ) emergency department and hospital encounters lasting less than $24 \mathrm{~h}, 3$ ) urgent care visits, and 4) outpatient (including telephonebased) encounters.

\section{Covariates}

We abstracted additional clinical and sociodemographic information on each child from the EHR, including sex, age, race, insurance type (public, private, self-pay), neighborhood socio-economic status (nSES), comorbidities (atopy, obesity), medication 


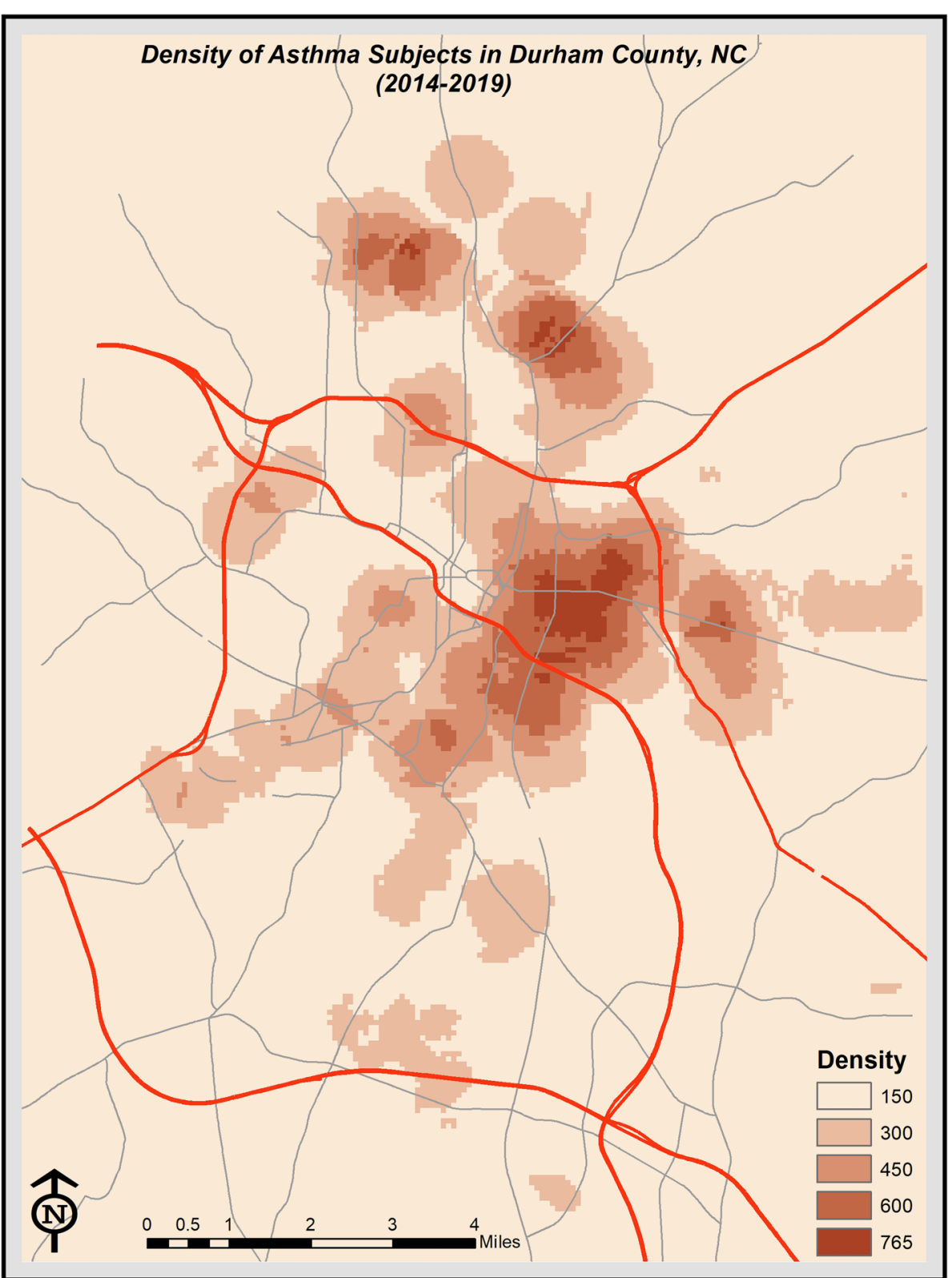

Fig. 2 Demonstration of radial density measures of 1.0 mile: we calculated the length of each type of highways within in a 1-mile buffer around each geocoded address location. This map was generated with ArcGIS software

categories (only rescue, only inhaled corticosteroids or only Leukotriene receptor antagonist, or other controller medications), and number of overall encounters. Covariates were treated as time-varying and abstracted accordingly. We considered any prescription order in the past 365 days as current. To calculate nSES, we identified each child's census tract and linked data from the American Community Survey to calculate the Agency for Healthcare Research and Quality (AHRQ) neighborhood deprivation index [34], generating a score between 0 and 100, with higher scores indicative of greater deprivation.

\section{Air quality exposure}

To further characterize potential exposures, we abstracted publicly available data from Environmental Protection Agency sensors on daily PM2.5 [35]. We note that Durham County only has one sensor, providing a general approximation of daily PM2.5 exposure.

\section{Statistical analysis}

We constructed a time-varying dataset in countingprocess format, generating an encounter row each time a child moved (i.e., changed primary exposure) or had an asthma exacerbation. All time-varying covariates (e.g., 
medications) were calculated based on these encounter points. We categorized patients based on their baseline distance to roadway, compared clinical and demographic differences among these groups, and calculated the number of exacerbations per patient-year.

To assess the relationship between distance to roadway and asthma exacerbation rates we performed a survival time-to-event analysis, treating distance as a timevarying exposure. We fit separate models for straightline distance and roadway radial density. In our cohort, about $25 \%$ of children had more than one asthma exacerbation over the study period. To account for multiple exacerbations, we conducted a recurrent events survival analysis using Andersen-Gill models [36]. As a sensitivity analysis, we used the Prentice, Williams and Peterson model and frailty model (random effects approach) as alternative recurrent events models [37]. Four different models were fit: 1) unadjusted; 2) adjusted for nSES; 3 ) adjusted for sex, age, race, and insurance type; and 4) adjusted for all the other covariates specified above. Additionally, we assessed the linearity of the effect of distance to roadways and roadway radial density on asthma exacerbation outcomes. We categorized our distance to roadways variables into quartiles and refitted the models. We also stratified on sex, race, and assessed time to outcome specific tiers.

All the statistical analyses were perform using $\mathrm{R}$ version 3.6.0.

\section{Results}

Our analytic cohort consisted of 6395 children with asthma, 187 of whom had invalid addresses and were excluded. Among the remaining 6208 children with asthma, we identified 6511 unique addresses and 3739 asthma exacerbations ( 2 exacerbations per 10 patient years). Around half of the unique addresses represented in the cohort were within 1 mile of a $55 \mathrm{MPH}+$ roadway among the unique addresses. Baseline characteristics are shown in Table 1. We first categorized patients based on their baseline initial straight-line distance to roadway: less than 0.25 mile, $0.25-0.5$ mile, $0.5-1$ mile, and greater than 1 mile - which roughly corresponded to the 10th, 25th and 50th quartiles. The median age of the cohort was $\sim 9$ years old and the majority of children were African Americans ( 60\%). Lower nSES scores were associated with residential locations close to roadways. There were no observed associations between asthma-related clinical factors (i.e. atopy, obesity, medication, and number of encounters in past year) and distance to roadway.

We assessed the relationship between distance to roadway and asthma exacerbation rates. We observed negligible relationships between distance to $55+\mathrm{MPH}$ roadways and overall, inpatient, emergency department, urgent, and outpatient asthma exacerbations, both before and after adjustment (Table 2). While the results suggest some slight protective effect for living further from a roadway, most of the confidence intervals crossed 1. Examining distance to $35+\mathrm{MPH}$ roadways and asthma exacerbation rates, there was a clear lack of association, as the results were less consistent and the confidence intervals were much wider (Table 3). Results were consistent when considering alternative statistical models (Appendix Table 3).

We further assessed the relationship between the density of roadways within census tracts and risk of exacerbation, but found minimal associations (Tables 4 \& 5). Finally, we assessed whether there was a non-linear association by evaluating distance groupings of $0-0.25$ miles, 0.25-0.5 miles, $0.5-1$ mile, 1 mile + (Fig. 3). Overall, there was no suggestion that children living closest to roadways had increased risk of asthma exacerbation. We performed sensitivity analyses stratified on age and sex and found results consistent across strata (results not shown).

In order to further contextualize our results, we assessed daily PM2.5 levels during the study period (Fig. 4). The exposure limit for PM2.5 is $35 \mu \mathrm{g} / \mathrm{m}^{3}$ [38]. As shown in this plot, there was only period that exceeded this limit from 2014 to 2019 - corresponding to wildfires in the region.

\section{Discussion}

In this study, we used EHR data to assess the association between residential distance to roadways on asthma exacerbation in children. There are a number of studies suggesting that proximity to high traffic areas, including roadways, have adverse effects on child respiratory health [39, 40], hospital admissions for asthma [41], pulmonary function [42, 43], and atopy [44], and there is some evidence that early life exposure to traffic-related pollution affects later asthma outcomes [45]. For instance, a cohort study by Deng et al. surveyed 2598 preschool children and demonstrated that maternal exposure to $\mathrm{NO}_{2}$ during the late pregnancy period could be associated with a higher risk of developing pediatric asthma, allergic rhinitis, and eczema [46]. Similarly, a Swedish birth cohort indicated that exposure to trafficrelated air pollution during infancy could be linked to lung function decrements in children through adolescence $[47,48]$. In our assessment of exacerbation rates in children with diagnosed asthma, we found a negligible relationship between distance from 55+ MPH roadway and any asthma exacerbation. Distance from 35+ MPH roads did not affect exacerbations at all.

Though our results were negative, our study has a number of strengths that differentiates it from prior work. For one, our cohort was relatively large compared with previous studies, ranging from 2 times to 15 times 
Table 1 Baseline Patient Characteristics by Distance to Highway (55+) Categories

\begin{tabular}{|c|c|c|c|c|}
\hline & $\begin{array}{l}<0.25 \text { mile } \\
N=776\end{array}$ & $\begin{array}{l}0.25-0.5 \text { mile } \\
N=988\end{array}$ & $\begin{array}{l}0.5-1 \text { mile } \\
N=1545\end{array}$ & $\begin{array}{l}>1 \text { mile } \\
N=3202\end{array}$ \\
\hline \multicolumn{5}{|l|}{ Sex } \\
\hline Male & $441(56.8 \%)$ & $566(57.3 \%)$ & 848 (54.9\%) & $1803(56.3 \%)$ \\
\hline Female & $335(43.2 \%)$ & $422(42.7 \%)$ & $697(45.1 \%)$ & $1399(43.7 \%)$ \\
\hline Age & $8.0(6.0-12.0)$ & $9.0(6.0-13.0)$ & $9.0(6.0-12.0)$ & $9.0(6.0-13.0$ \\
\hline \multicolumn{5}{|l|}{ Race } \\
\hline Hispanic & $154(19.8 \%)$ & $91(9.2 \%)$ & $221(14.3 \%)$ & $326(10.2 \%)$ \\
\hline Non-Hispanic Black & 465 (59.9\%) & $662(67.0 \%)$ & $888(57.5 \%)$ & $1814(56.7 \%)$ \\
\hline Non-Hispanic White & 90 (11.6\%) & $143(14.5 \%)$ & $276(17.9 \%)$ & 773 (24.1\%) \\
\hline Other & $54(7.0 \%)$ & $74(7.5 \%)$ & $118(7.6 \%)$ & $224(7.0 \%)$ \\
\hline Unavailable/Unknown & $13(1.7 \%)$ & $18(1.8 \%)$ & $42(2.7 \%)$ & $65(2.0 \%)$ \\
\hline \multicolumn{5}{|l|}{ Atopy } \\
\hline No & $293(37.8 \%)$ & $354(35.8 \%)$ & $628(40.6 \%)$ & $1211(37.8 \%)$ \\
\hline Yes & $483(62.2 \%)$ & $634(64.2 \%)$ & 917 (59.4\%) & $1991(62.2 \%)$ \\
\hline \multicolumn{5}{|l|}{ Obesity } \\
\hline No & $561(72.3 \%)$ & 707 (71.6\%) & $1083(70.1 \%)$ & $2426(75.8 \%)$ \\
\hline Yes & $206(26.5 \%)$ & $264(26.7 \%)$ & $446(28.9 \%)$ & 749 (23.4\%) \\
\hline Missing & $9(1.2 \%)$ & 17 (1.7\%) & $16(1.0 \%)$ & $27(0.8 \%)$ \\
\hline \multicolumn{5}{|l|}{ Insurance Type } \\
\hline Private & 179 (23.1\%) & $290(29.4 \%)$ & $494(32.0 \%)$ & $1313(41.0 \%)$ \\
\hline Public & $565(72.8 \%)$ & $648(65.6 \%)$ & $985(63.8 \%)$ & $1746(54.5 \%)$ \\
\hline Self-pay & $29(3.7 \%)$ & $44(4.5 \%)$ & $62(4.0 \%)$ & $118(3.7 \%)$ \\
\hline Unavailable/Unknown & $3(0.4 \%)$ & $6(0.6 \%)$ & $4(0.3 \%)$ & $25(0.8 \%)$ \\
\hline \multicolumn{5}{|l|}{ Medication Category } \\
\hline No prescriptions & $475(61.2 \%)$ & $577(58.4 \%)$ & 917 (59.4\%) & $1890(59.0 \%)$ \\
\hline Only ICS or only LTRA & $229(29.5 \%)$ & $346(35.0 \%)$ & $510(33.0 \%)$ & $1095(34.2 \%)$ \\
\hline Combination & $72(9.3 \%)$ & $65(6.6 \%)$ & $118(7.6 \%)$ & $217(6.8 \%)$ \\
\hline \multicolumn{5}{|l|}{ SES Status Category } \\
\hline $25-50$ & $414(53.4 \%)$ & $663(67.1 \%)$ & $927(60.0 \%)$ & $1485(46.4 \%)$ \\
\hline $50-75$ & $260(33.5 \%)$ & $318(32.2 \%)$ & $616(39.9 \%)$ & $1717(53.6 \%)$ \\
\hline Missing & $102(13.1 \%)$ & $7(0.7 \%)$ & $2(0.1 \%)$ & $0(0.0 \%)$ \\
\hline Number of Encounters in past year & $2.0(1.0-5.0)$ & $2.0(1.0-5.0)$ & $2.0(1.0-5.0)$ & $3.0(1.0-5.0)$ \\
\hline
\end{tabular}

ICS Inhaled corticosteroids, LTRA Leukotriene receptor antagonist, SES Socio-economic Status

Table 2 Association Between Asthma Exacerbations and Distances to 55+ MPH Highways

\begin{tabular}{|c|c|c|c|c|c|c|c|c|c|}
\hline & \multirow[t]{2}{*}{$\begin{array}{l}\text { Number } \\
\text { of } \\
\text { events }\end{array}$} & \multicolumn{2}{|c|}{ Unadjusted } & \multicolumn{2}{|c|}{ + Adjustment for SES Score } & \multicolumn{2}{|c|}{$\begin{array}{l}\text { + Adjustment for Race/Insurance/ } \\
\text { Sex/Age }\end{array}$} & \multicolumn{2}{|c|}{$\begin{array}{l}\text { Adjustment for Number } \\
\text { of Encounter/ Medication/ } \\
\text { Obesity/Atopy }\end{array}$} \\
\hline & & HR & $95 \% \mathrm{Cl}$ & HR & $95 \% \mathrm{Cl}$ & HR & $95 \% \mathrm{Cl}$ & $\overline{H R}$ & $95 \% \mathrm{Cl}$ \\
\hline Overall & 3739 & 0.98 & $0.94,1.01$ & 0.98 & $0.94,1.02$ & 0.99 & $0.95,1.02$ & 0.99 & $0.96,1.02$ \\
\hline Inpatient & 304 & 1.00 & $0.94,1.06$ & 0.98 & $0.91,1.05$ & 0.98 & $0.90,1.06$ & 0.97 & $0.89,1.06$ \\
\hline ED & 895 & 0.96 & $0.90,1.02$ & 0.97 & $0.91,1.03$ & 0.97 & $0.92,1.03$ & 0.98 & $0.93,1.03$ \\
\hline Urgent & 935 & 0.93 & $0.89,0.98$ & 0.93 & $0.89,0.97$ & 0.94 & $0.89,0.98$ & 0.94 & $0.89,0.99$ \\
\hline Outpatient & 1850 & 0.99 & $0.96,1.02$ & 1.00 & $0.97,1.03$ & 1.00 & $0.97,1.03$ & 0.99 & $0.96,1.03$ \\
\hline
\end{tabular}


Table 3 Association Between Asthma Exacerbations and Distances to 35+ MPH Roadways

\begin{tabular}{|c|c|c|c|c|c|c|c|c|c|}
\hline & \multirow[t]{2}{*}{$\begin{array}{l}\text { Number } \\
\text { of } \\
\text { events }\end{array}$} & \multicolumn{2}{|c|}{ Unadjusted } & \multicolumn{2}{|c|}{$\begin{array}{l}\text { + Adjustment for SES } \\
\text { Score }\end{array}$} & \multicolumn{2}{|c|}{$\begin{array}{l}\text { + Adjustment for Race/ } \\
\text { Insurance/ } \\
\text { Sex/Age }\end{array}$} & \multicolumn{2}{|c|}{$\begin{array}{l}\text { + Adjustment for Number of } \\
\text { Encounter/ } \\
\text { Medication/Obesity/ } \\
\text { Atopy }\end{array}$} \\
\hline & & $\overline{H R}$ & $95 \% \mathrm{Cl}$ & HR & $95 \% \mathrm{Cl}$ & $\mathrm{HR}$ & $95 \% \mathrm{Cl}$ & $\overline{H R}$ & $95 \% \mathrm{Cl}$ \\
\hline Overall & 3739 & 0.98 & $0.83,1.15$ & 0.98 & $0.83,1.16$ & 1.02 & $0.86,1.21$ & 1.00 & $0.85,1.18$ \\
\hline Inpatient & 304 & 1.25 & $0.89,1.75$ & 1.20 & $0.86,1.69$ & 1.34 & $0.96,1.86$ & 1.10 & $0.80,1.52$ \\
\hline ED & 895 & 1.00 & $0.79,1.27$ & 1.03 & $0.81,1.31$ & 1.06 & $0.83,1.35$ & 1.07 & $0.83,1.38$ \\
\hline Urgent & 935 & 0.88 & $0.70,1.10$ & 0.87 & $0.69,1.09$ & 0.89 & $0.70,1.12$ & 0.82 & $0.65,1.04$ \\
\hline Outpatient & 1850 & 0.99 & $0.86,1.14$ & 1.01 & $0.87,1.17$ & 1.02 & $0.88,1.18$ & 0.99 & $0.85,1.15$ \\
\hline
\end{tabular}

HR Hazard ratio 95\%, Cl 95\% Confidence interval, ED Emergency department, SES Socio-economic Status

larger $[16,19,24,26,28]$. Moreover, the majority of previous studies used questionnaires to collect information $[19,24,28]$. Such questionnaires are frequently complicated and time-consuming, and, because questionnaires rely on self-reports, they can cause some potential misclassification due to recall bias for outcomes and/or exposures [26]. Instead of relying on self-report, we directly extracted patient information from the EHR system, which efficiently provides data on a large number of individuals and avoids biases found with self-reported data.

The lack of significant association between residential distance to roadway and asthma exacerbation rates could potentially be explained by factors related to air quality and the built environment of Durham. First, the air quality in Durham is generally good (Fig. 4). Other studies that reported a weak or no association between asthma and traffic-related air pollution evaluated populations living in locations with good air quality, such as Sweden, Norway, and Germany [6, 26-28]. Based on the worldwide air quality rankings for mid-2019, the air quality index for these countries were $17.45,20.29$ and 28.42 respectively [49]. In contrast, studies that reported strong associations were conducted in places such as the United Kingdom, Poland, and South Korea, whose air pollution indexes were $40.63,52.88$, and 54.80 , respectively [2224, 50]. Similar trends have been reported within the United States. A study conducted in Los Angeles reported that children and adults who suffer from asthma and live close to traffic are nearly three times more likely to visit the emergency department or be hospitalized than those who live near low traffic density [18]. In fact, cities in California, including Los Angeles, have ranked to have the worst particle pollution in the US [51].

A second reason our results may differ is that compared to other studies our cohort lived further from roadways. Multiple studies reported a threshold of $150 \mathrm{~m}(\sim 0.1 \mathrm{mile})$ for finding the highest concentrations of traffic-related pollutions [17, 24]. However, in our cohort, only 283 children live within this proximity to roadways. Two previous studies in California and South Korea utilizing radial density measures similar to ours found effects only at much closer distances of $500 \mathrm{ft}$ and $200 \mathrm{~m}$ respectively, than the 1mile buffer we used [22, 24].

Only one other study, conducted in Minnesota, has utilized EHR data to assess the relationship between asthma exacerbation and traffic-related air pollution [52]. The authors used vehicle kilometers traveled within $250 \mathrm{~m}$ and $500 \mathrm{~m}$ of each individual's residence, as well as the traffic density as their exposures. Traffic exposures is similar to the radial density measures in our study. Assessing both pediatric and adult patients, the authors reported that traffic exposure at the residence increases the risk of asthma exacerbations. The authors

Table 4 Association Between Asthma Exacerbations and 1-mile Buffer Density Measurement Around 55+ MPH Highways

\begin{tabular}{|c|c|c|c|c|c|c|c|c|c|}
\hline & \multirow[t]{2}{*}{$\begin{array}{l}\text { Number } \\
\text { of } \\
\text { events }\end{array}$} & \multicolumn{2}{|c|}{ Unadjusted } & \multicolumn{2}{|c|}{$\begin{array}{l}\text { + Adjustment for SES } \\
\text { Score }\end{array}$} & \multicolumn{2}{|c|}{$\begin{array}{l}\text { + Adjustment for Race/ } \\
\text { Insurance/ } \\
\text { Sex/Age }\end{array}$} & \multicolumn{2}{|c|}{$\begin{array}{l}\text { + Adjustment for Number of } \\
\text { Encounter/ } \\
\text { Medication/Obesity/ } \\
\text { Atopy }\end{array}$} \\
\hline & & HR & $95 \% \mathrm{Cl}$ & HR & $95 \% \mathrm{Cl}$ & HR & $95 \% \mathrm{Cl}$ & HR & $95 \% \mathrm{Cl}$ \\
\hline Overall & 1854 & 0.98 & $0.93,1.04$ & 0.98 & $0.93,1.02$ & 0.99 & $0.94,1.03$ & 0.98 & $0.94,1.02$ \\
\hline Inpatient & 168 & 1.01 & $0.92,1.11$ & 1.04 & $0.93,1.17$ & 1.05 & $0.92,1.19$ & 1.02 & $0.92,1.13$ \\
\hline ED & 497 & 0.98 & $0.93,1.04$ & 0.96 & $0.90,1.02$ & 0.97 & $0.90,1.03$ & 0.98 & $0.92,1.05$ \\
\hline Urgent & 497 & 0.98 & $0.9,1.03$ & 0.99 & $0.94,1.04$ & 0.99 & $0.94,1.05$ & 1.00 & $0.95,1.06$ \\
\hline Outpatient & 824 & 1.05 & $0.98,1.12$ & 1.03 & $0.98,1.09$ & 1.03 & $0.97,1.08$ & 1.03 & $0.97,1.08$ \\
\hline
\end{tabular}

HR Hazard ratio 95\%, Cl 95\% Confidence interval, ED Emergency department, SES Socio-economic Status 
Table 5 Association Between Asthma Exacerbations and 1-mile Buffer Density Measurement Around 35+ MPH Roadways

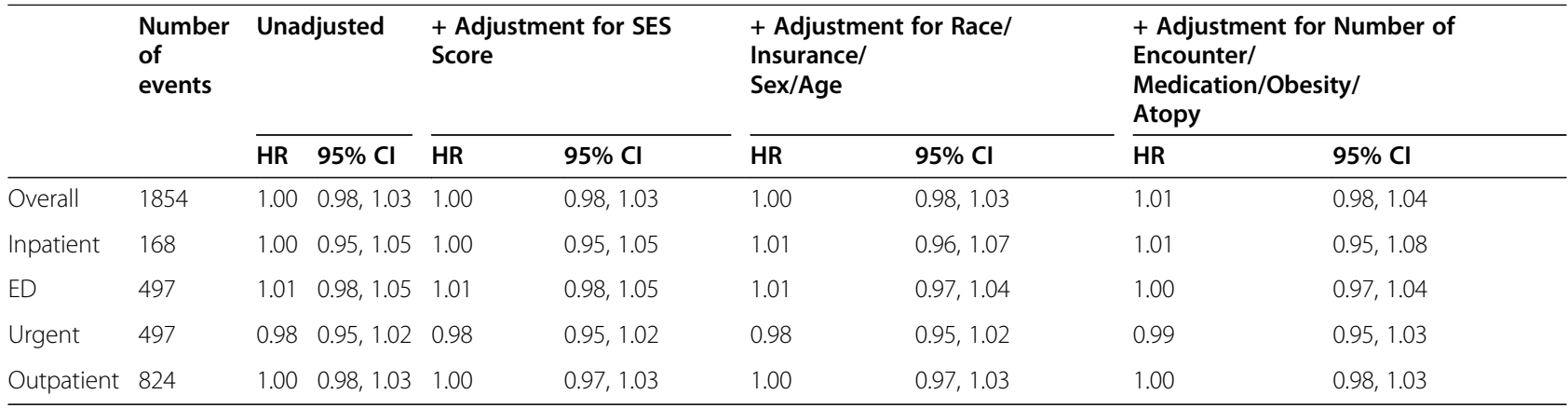

HR Hazard ratio 95\%, Cl 95\% Confidence interval, ED Emergency department, SES Socio-economic Status

reported lower odds ratio for vehicle kilometers traveled within $500 \mathrm{~m}$ than the vehicle kilometers traveled within $250 \mathrm{~m}$ and affirmed that $500 \mathrm{~m}$ buffer distance does not effectively capture the traffic effect. Moreover, while air quality across Minnesota is generally within the healthy range, there are several days each year where fine particles levels can exceed to the unhealthy levels [53]. Overall this paper helps to contextualize some of the present findings highlighting that it is both close exposure to roadways that matters and that there may be air quality threshold that an environment needs to drop below.
One challenge in studying the effect of one's distance to highway on risk of asthma exacerbation is that we are assessing the effect of chronic exposure on an acute outcome. It is likely that such chronic exposures will have a greater impact on longer term disease progression, where more acute changes in one's environment will more directly impact one's risk of exacerbation. Ultimately, any association between distance to roadways and asthma is going to be mediated through environmental air quality. Therefore, future work should seek to not only measure an individual's distance to highway but the ambient air

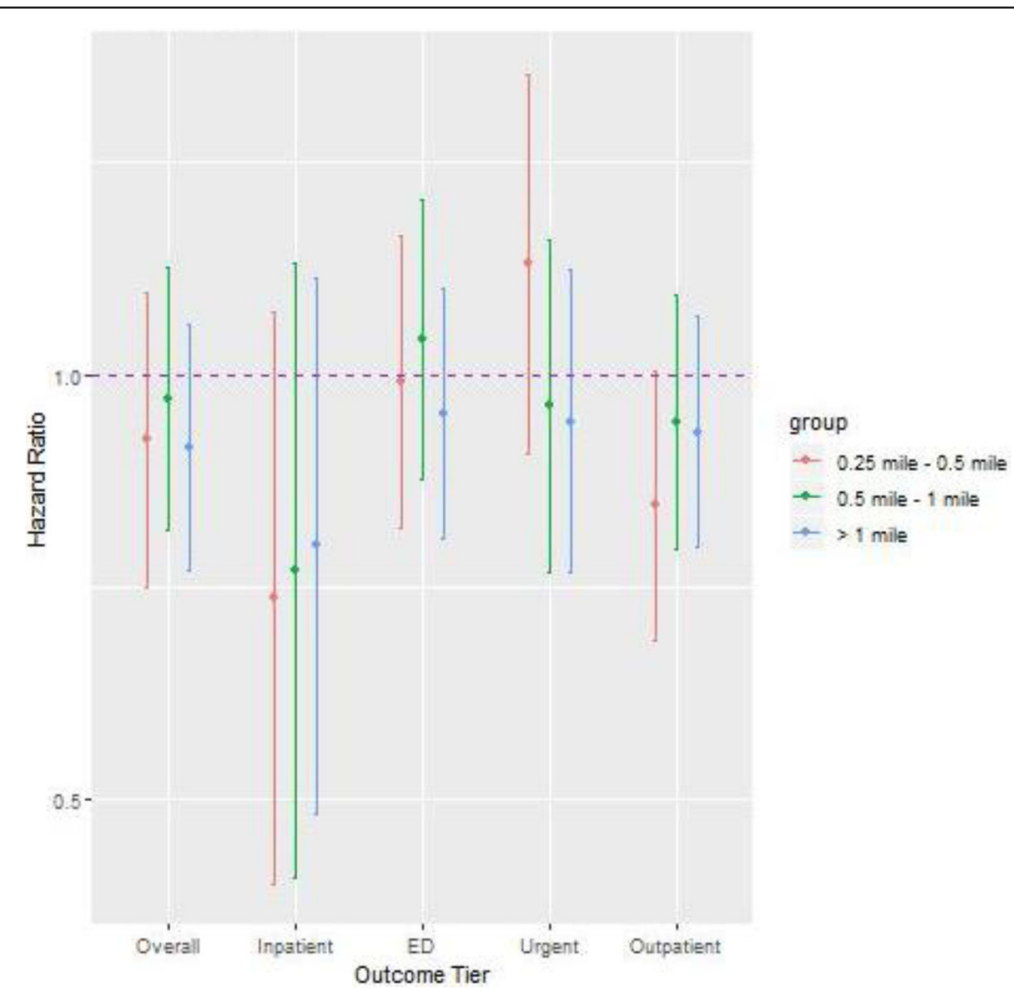

Fig. 3 Assessment of non-linear associations between asthma exacerbation and distance to roadways among different distance groupings for different outcome tiers. The reference group here is $<0.25$ mile, and there is no evidence showing children living closest to roadways had increased risk of asthma exacerbation 


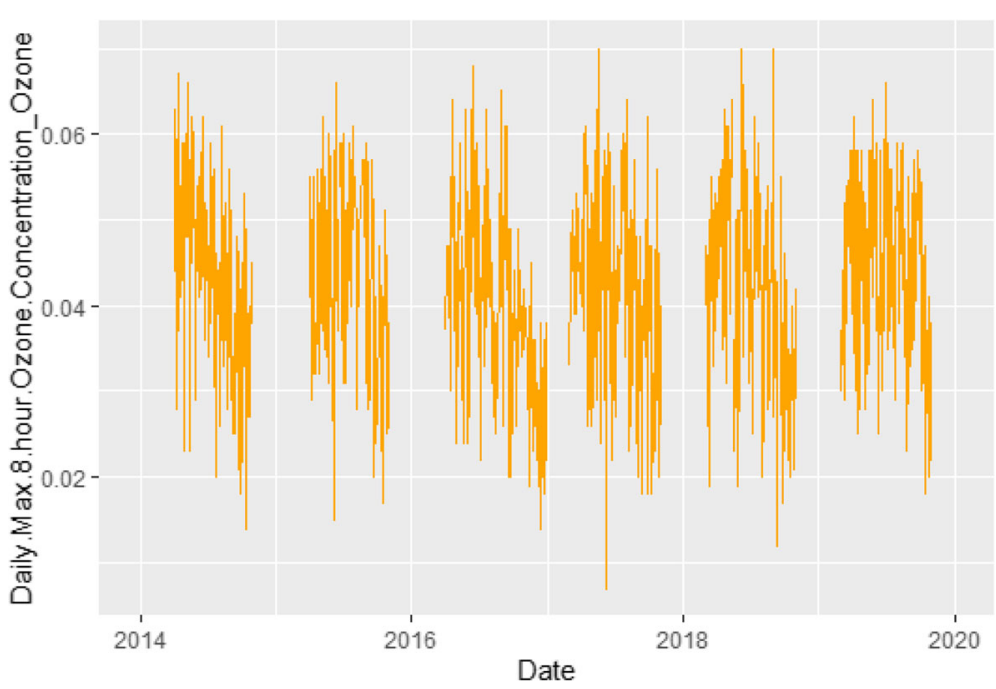

Fig. 4 Daily 8-h maximum PM2.5 levels from 2014 to 2019. The recommended exposure limit for PM2.5 is $35 \mu \mathrm{g} / \mathrm{m}^{3}$. There was only one period fall of 2017, corresponding to wild fires in the region - that exceeded this threshold

quality in their neighborhood. With newer technology in satellite imaging, it is possible to more finely map neighborhood air quality [54].

There are a few limitations in our study. While our results suggest no association between residential distance to roadway and asthma exacerbation rates, a null result is hard to prove, as statistical tests are not designed to detect them. Moreover, our results are limited to one geographic area. As we noted above, Durham County has several unique characteristics, including relatively good air quality, which may cause effect heterogeneity between studies. Additionally, highway exposure is only one form of environmental exposure that can impact risk of asthma exacerbation. Indoor air quality, seasonal factors and smoking exposure are environmental factors that we were not able to account for in this analysis. Finally, while we believe that the use of EHR data produces more objective data measurements, EHR data are prone to their own biases [55]. In particular, type of health service utilization is often a reflection of both severity of disease as well as other social factors such as SES and health seeking behavior. Of note, our analyses did not indicate confounding due to nSES.

\section{Conclusion}

In conclusion, this study shows that proximity to roadways is not strongly associated with asthma exacerbation rates in Durham County from 2014 to 2019. Comparing these findings with reports from other locations, suggests that both close proximity and overall air quality are perhaps important modifiers of the association. Moreover, it illustrates how EHR data, combined with environmental data, can be used to assess environmental effects on population health.

\section{Supplementary Information}

Supplementary information accompanies this paper at https://doi.org/10. 1186/s12889-020-09731-0.

\section{Additional file 1.}

\section{Abbreviations}

EHR: Electronic health records; ICD: International classification of disease;

GIS: Geographic information software; MPH: Miles per hour;

nSES: Neighborhood socioeconomic status; PM: Particulate matter;

SES: Socioeconomic status

Acknowledgements

Not applicable.

Consent for publications

Not Applicable.

Data permission

The primary health used are not publicly available. Data were extracted from the Duke University Health System electronic health record system under IRB permission.

\section{Authors' contributions}

$J \mathrm{H}$ analyzed the data and drafted the manuscript. MGG performed ArcGIS analysis. BAG, JL and $J H H$ edited the manuscript, MT and BA interpreted the results. $J \mathrm{~L}$ and BAG procured funding. All authors have read and approve this manuscript.

\section{Funding}

This work was supported by National Institute of Heart, Lung and Blood Institute (NHLBI) R21-HL145415 (BAG, JL). The project described was supported by the National Center for Advancing Translational Sciences (NCATS), National Institutes of Health $(\mathrm{NIH})$, through Grant Award Number

UL1TR001117 at Duke University. The content is solely the responsibility of the authors and does not necessarily represent the official views of the $\mathrm{NIH}$.

\section{Availability of data and materials}

The analysis data is not available as it contains protected health information. An anonymized data set is not available upon request. 


\section{Ethics approval and consent to participate}

This study was approved by the Duke University School of Medicine IRB, Pro00091342.

\section{Competing interests}

We have no Conflict of Interests to Report.

\section{Author details}

${ }^{1}$ Department of Biostatistics \& Bioinformatics, Duke University, 2424 Erwin Road, Durham, NC 27705, USA. 'Duke Clinical Research Institute, Durham, NC, USA. ${ }^{3}$ Children's Health \& Discovery Initiative, Duke University, Durham, NC, USA. ${ }^{4}$ Department of Pediatrics, Duke University, Durham, USA. ${ }^{5}$ Department of Medicine, University California, San Francisco, USA.

Received: 2 July 2020 Accepted: 19 October 2020

Published online: 29 October 2020

\section{References}

1. Zahran HS, Bailey CM, Damon SA, Garbe PL, Breysse PN. Vital Signs: Asthma in Children - United States, 2001-2016. MMWR Morb Mortal Wkly Rep. 2018; 67(5):149-55. Published 2018 Feb 9. https://doi.org/10.15585/mmwr. mm6705e1.

2. Asthma Facts and Figures - Asthma and Allergy Foundation of America. https://www.aafa.org/asthma-facts/. Accessed January 26, 2020.

3. Jackson DJ, Sykes A, Mallia P, Johnston SL. Asthma exacerbations: origin, effect, and prevention. J Allergy Clin Immunol. 2011;128:1165-74. https:// doi.org/10.1016/j.jaci.2011.10.024.

4. Asthma-related Missed School Days among Children aged 5-17 Years Centers for Disease Control and Prevention. https://www.cdc.gov/asthma/ asthma_stats/missing_days.htm. Accessed February 13, 2018.

5. Gauderman WJ, Avol E, Lurmann F, et al. Childhood asthma and exposure to traffic and nitrogen dioxide. Epidemiology. 2005;16(6):737-43. https://doi. org/10.1097/01.ede.0000181308.51440.75.

6. Nordling E, Berglind N, Melén E, et al. Traffic-related air pollution and childhood respiratory symptoms, function and allergies. Epidemiology. 2008; 19:401-8. https://doi.org/10.1097/EDE.0b013e31816a1ce3.

7. Bouazza N, Foissac F, Urien S, et al. Fine particulate pollution and asthma exacerbations. Arch Dis Child. 2018;103(9):828-31. https://doi.org/10.1136/ archdischild-2017-312826.

8. Guarnieri M, Balmes JR. Outdoor air pollution and asthma. Lancet. 2014; 383(9928):1581-92. https://doi.org/10.1016/S0140-6736(14)60617-6.

9. Anenberg SC, Henze DK, Tinney V, et al. Estimates of the Global Burden of Ambient $\mathrm{PM}_{2.5}$, Ozone, and $\mathrm{NO}_{2}$ on Asthma Incidence and Emergency Room Visits. Environ Health Perspect. 2018;126(10):107004. https://doi.org/ 10.1289/EHP3766.

10. Kim JJ. American Academy of Pediatrics Committee on environmenta health. Ambient air pollution: health hazards to children. Pediatrics. 2004; 114(6):1699-707. https://doi.org/10.1542/peds.2004-2166.

11. Liu Y, Pan J, Zhang $H$, et al. Short-term exposure to ambient air pollution and asthma mortality. Am J Respir Crit Care Med. 2019;200(1):24-32. https:// doi.org/10.1164/rccm.201810-18230C.

12. Lovinsky-Desir S, Acosta LM, Rundle AG, et al. Air pollution, urgent asthma medical visits and the modifying effect of neighborhood asthma prevalence. Pediatr Res. 2019;85(1):36-42. https://doi.org/10.1038/s41390018-0189-3.

13. Batterman SA, Zhang K, Kononowech R. Prediction and analysis of nearroad concentrations using a reduced-form emission/dispersion model. Environ Health. 2010;9:29. Published 2010 Jun 25. https://doi.org/10.1186/ 1476-069X-9-29.

14. Ginzburg H, Liu X, Baker M, et al. Monitoring study of the near-road PM2.5 concentrations in Maryland. J Air Waste Manage Assoc. 2015;65(9):1062-71. https://doi.org/10.1080/10962247.2015.1056887.

15. Urman R, Eckel $\mathrm{S}$, Deng $\mathrm{H}$, et al. Risk effects of near-roadway pollutants and asthma status on bronchitic symptoms in children. Environ Epidemiol. 2018; 2(2):e012. https://doi.org/10.1097/EE9.0000000000000012.

16. Hauptman M, Gaffin JM, Petty CR, et al. Proximity to major roadways and asthma symptoms in the School Inner-City Asthma Study. J Allergy Clin Immunol. 2020;145(1):119-126.e4. https://doi.org/10.1016/j.jaci.2019.08.038.

17. Venn A, Yemaneberhan H, Lewis S, Parry E, Britton J. Proximity of the home to roads and the risk of wheeze in an Ethiopian population. Occup Environ Med. 2005;62(6):376-80. https://doi.org/10.1136/oem.2004.017228.
18. Meng YY, Rull RP, Wilhelm M, et al. Living near heavy traffic increases asthma severity. Policy Brief UCLA Cent Health Policy Res. 2006:1-5.

19. Gehring U, Wijga AH, Brauer M, et al. Traffic-related air pollution and the development of asthma and allergies during the first 8 years of life. Am J Respir Crit Care Med. 2010;181(6):596-603. https://doi.org/10.1164/rccm. 200906-08580C.

20. Ryan PH, Lemasters GK, Biswas $P$, et al. A comparison of proximity and land use regression traffic exposure models and wheezing in infants. Environ Health Perspect. 2007;115(2):278-84. https://doi.org/10.1289/ehp.9480.

21. Brauer M, Hoek G, Smit HA, et al. Air pollution and development of asthma, allergy and infections in a birth cohort. Eur Respir J. 2007;29(5):879-88. https://doi.org/10.1183/09031936.00083406.

22. Livingstone AE, Shaddick G, Grundy C, Elliott P. Do people living near inner city main roads have more asthma needing treatment? Case control study. BMJ. 1996:312(7032):676-7. https://doi.org/10.1136/bmj.312.7032.676.

23. Porebski G, Woźniak M, Czarnobilska E. Residential proximity to major roadways is associated with increased prevalence of allergic respiratory symptoms in children. Ann Agric Environ Med. 2014;21(4):760-6. https://doi. org/10.5604/12321966.1129929.

24. Lee JY, Leem JH, Kim HC, et al. Effects of traffic-related air pollution on susceptibility to infantile bronchiolitis and childhood asthma: a cohort study in Korea. J Asthma. 2018;55(3):223-30. https://doi.org/10.1080/02770903. 2017.1313270.

25. Huynh P, Salam MT, Morphew T, Kwong KY, Scott L. Residential Proximity to Freeways is Associated with Uncontrolled Asthma in Inner-City Hispanic Children and Adolescents. J Allergy (Cairo). 2010;2010:157249. https://doi. org/10.1155/2010/157249.

26. Oftedal B, Nystad W, Brunekreef B, Nafstad P. Long-term traffic-related exposures and asthma onset in schoolchildren in Oslo, Norway. Environ Health Perspect. 2009:117(5):839-44. https://doi.org/10.1289/ehp.11491.

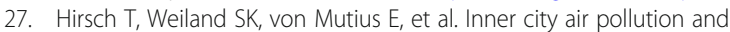
respiratory health and atopy in children. Eur Respir J. 1999;14(3):669-77. https://doi.org/10.1034/j.1399-3003.1999.14c29.x.

28. Mölter A, Agius $R$, de Vocht $F$, et al. Effects of long-term exposure to PM10 and NO2 on asthma and wheeze in a prospective birth cohort. J Epidemiol Community Health. 2014;68(1):21-8. https://doi.org/10.1136/jech-2013202681.

29. Miranda ML, Ferranti J, Strauss B, Neelon B, Califf RM. Geographic health information systems: a platform to support the 'triple aim'. Health Aff (Millwood). 2013;32(9):1608-15. https://doi.org/10.1377/hlthaff.2012.1199.

30. Tang M, Goldstein BA, He J, Hurst JH, Lang JE. Performance of a computable phenotype for pediatric asthma using the problem list [published online ahead of print, 2020 Jul 17]. Ann Allergy Asthma Immunol. 2020;510811206(20):30486-5. https://doi.org/10.1016/j.anai.2020.07.009.

31. Wang $Y$, Eliot MN, Kuchel GA, et al. Long-term exposure to ambient air pollution and serum leptin in older adults: results from the MOBILIZE Boston study. J Occup Environ Med. 2014:56(9):e73-7. https://doi.org/10. 1097/JOM.0000000000000253.

32. Wang $Y$, Eliot MN, Koutrakis $P$, et al. Ambient air pollution and depressive symptoms in older adults: results from the MOBILIZE Boston study. Environ Health Perspect. 2014;122(6):553-8. https://doi.org/10.1289/ehp.1205909.

33. Wellenius GA, Boyle LD, Coull BA, et al. Residential proximity to nearest major roadway and cognitive function in community-dwelling seniors: results from the MOBILIZE Boston study. J Am Geriatr Soc. 2012;60(11):207580. https://doi.org/10.1111/j.1532-5415.2012.04195.x.

34. Bonito AJ, Bann C, Eicheldinger C, Carpenter L. Creation of new raceethnicity codes and socioeconomic status (SES) indicators for Medicare beneficiaries: final report, sub-task 21. Rockville, MD: Agency for Healthcare Research and Quality; 2008. AHRQ Publication 08-0029-EF.

35. National Centers for Environmental Information. https://www.ncdc.noaa. gov/. Accessed December 24, 2019.

36. Andersen PK, Gill RD. Cox's regression model for counting processes: a large sample study. Ann Stat. 1982;10(4):1100-20.

37. Prentice RL, Williams BJ, Peterson AV. On the regression analysis of multivariate failure time data. Biometrika. 1981;68(2):373-9.

38. What are the Air Quality Standards for PM?. United States Environmental Protection Agency. https://www3.epa.gov/region1/airquality/pm-aqstandards.html. Accessed January 09, 2020.

39. Ciccone G, Forastiere F, Agabiti N, et al. Road traffic and adverse respiratory effects in children. SIDRIA Collaborative Group. Occup Environ Med. 1998; 55(11):771-8. https://doi.org/10.1136/oem.55.11.771. 
40. Salam MT, Islam T, Gilliland FD. Recent evidence for adverse effects of residential proximity to traffic sources on asthma. Curr Opin Pulm Med. 2008;14(1):3-8. https://doi.org/10.1097/MCP.0b013e3282f1987a.

41. Edwards J, Walters S, Griffiths RK. Hospital admissions for asthma in preschool children: relationship to major roads in Birmingham, United Kingdom. Arch Environ Health. 1994;49(4):223-7. https://doi.org/10.1080/ 00039896.1994 .9937471$.

42. Margolis HG, Mann JK, Lurmann FW, et al. Altered pulmonary function in children with asthma associated with highway traffic near residence. Int J Environ Health Res. 2009;19(2):139-55. https://doi.org/10.1080/ 09603120802415792

43. Brunekreef B, Janssen NA, de Hartog J, Harssema H, Knape M, van Vliet P. Air pollution from truck traffic and lung function in children living near motorways. Epidemiology. 1997;8(3):298-303. https://doi.org/10.1097/ 00001648-199705000-00012.

44. Nicolai T, Carr D, Weiland SK, et al. Urban traffic and pollutant exposure related to respiratory outcomes and atopy in a large sample of children. Eur Respir J. 2003;21(6):956-63. https://doi.org/10.1183/09031936.03.00041103a.

45. Zmirou D, Gauvin S, Pin I, et al. Traffic related air pollution and incidence of childhood asthma: results of the Vesta case-control study. J Epidemiol Community Health. 2004;58(1):18-23. https://doi.org/10.1136/jech.58.1.18.

46. Deng Q, Lu C, Li Y, Sundell J. Dan Norbäck. Exposure to outdoor air pollution during trimesters of pregnancy and childhood asthma, allergic rhinitis, and eczema. Environ Res. 2016;150:119-27. https://doi.org/10.1016/j. envres.2016.05.050 Epub 2016 Jun 6. PMID: 27281689.

47. Schultz ES, Gruzieva O, Bellander T, et al. Traffic-related air pollution and lung function in children at 8 years of age: a birth cohort study. Am J Respir Crit Care Med. 2012;186(12):1286-91. https://doi.org/10.1164/rccm.20120610450C Epub 2012 Oct 26. PMID: 23103735.

48. Schultz ES, Hallberg J, Bellander T, et al. Early-life exposure to traffic-related air pollution and lung function in adolescence. Am J Respir Crit Care Med. 2016;193(2):171-7. https://doi.org/10.1164/rccm.201505-09280C PMID: 26397124.

49. Top 10 countries with the worst air pollution index - The World Air Quality Index project. https://aqicn.org/rankings/. Accessed January 12, 2020.

50. Pollution Index by Country 2020 - NUMBEO. https://www.numbeo.com/ pollution/rankings_by_country.jsp. Accessed January 12, 2020

51. Key Findings: The State of Air 2019 - American Lung Association. https:// www.lung.org/our-initiatives/healthy-air/sota/key-findings/. Accessed January 12, 2020.

52. Lindgren P, Johnson J, Williams A, Yawn B, Pratt GC. Asthma exacerbations and traffic: examining relationships using link-based traffic metrics and a comprehensive patient database. Environ Health. 2016;15(1):102. Published 2016 Nov 3. https://doi.org/10.1186/s12940-016-0184-2.

53. How's the air? - Minnesota Pollution Control Agency. https://www.pca.state. mn.us/air/hows-air. Accessed March 25, 2020.

54. Duncan BN, Prados Al, Lamsal LN, et al. Satellite data of atmospheric pollution for u.s. air quality applications: examples of applications, summary of data end-user resources, answers to FAQs, and common mistakes to avoid. Atmos Environ. 2014;94:647-62. https://doi.org/10.1016/.atmosenv. 2014.05.061

55. Phelan M, Bhavsar NA, Goldstein BA. Illustrating Informed Presence Bias in Electronic Health Records Data: How Patient Interactions with a Health System Can Impact Inference. EGEMS (Wash DC). 2017;5(1):22. Published 2017 Dec 6. https://doi.org/10.5334/egems.243.

\section{Publisher's Note}

Springer Nature remains neutral with regard to jurisdictional claims in published maps and institutional affiliations.

Ready to submit your research? Choose BMC and benefit from:
- fast, convenient online submission
- thorough peer review by experienced researchers in your field
- rapid publication on acceptance
- support for research data, including large and complex data types
- gold Open Access which fosters wider collaboration and increased citations
- maximum visibility for your research: over 100M website views per year
At BMC, research is always in progress.
Learn more biomedcentral.com/submissions

